\title{
THE ROLE OF GOVERNMENTAL CREDIT IN HEMISPHERIC TRADE
}

\author{
Frank Whitson FetTrR*
}

A recent development in the economic relations between the United States and Latin America has been the financing of trade by various agencies of the American government. This began on a modest scale in r934, but assumed importance only after the outbreak of the European War in September, 1939. At present writingDecember I, $\mathrm{I} 94 \mathrm{I}$-as a result both of new legislation and of developments in American foreign policy, this government credit seems likely to be a major factor in our economic relations with the republics of Latin America for some time to come.

The Export-Import Bank, as of August 15, x94i-the latest date for which full information is available-had outstanding in Latin America loans of nearly $\$ 37$ million, and commitments to loan an additional \$229 million, ${ }^{1}$ and has Congressional authorization to advance a total of $\$ 700$ million. The American Treasury has agreed to supply from the Stabilization Fund, $\$ 50$ million to the Central Bank of Argentina and $\$ 40$ million to the Bank of Mexico, to aid in stabilizing their currencies. The extensive purchase of silver by the Treasury under the Silver Purchase Act of 1934, and the operations of three subsidiaries of the Reconstruction Finance Corporation in purchasing and making commitments to purchase Latin American products, although perhaps not generally thought of as credit operations, by making available to Latin America several hundred million dollars have had substantially the same effect as credit operations.

Before 1934 credit had played an important role in our economic relations with Latin America, but with the exception of two transactions in 1917 and 1918 the American government had never extended credit in Latin America. In 19ז7, out of the proceeds of the Liberty Loans, \$ro million were loaned to Cuba, and later a small credit was granted to Nicaragua in connection with the sale of surplus war

*A.B., 1920, Swarthmore College; A.M., x924, Harvard University; A.M., 1922, Ph.D., 1926, Princeton University. Professor of Economics, Haverford College. Member, Commission on Cuban Affairs of the Foreign Policy Association, 1934; Economic Adviser to the Central Bank of Ecuador, 1940. Author, Monetary Inflatton in Chile (1931); Co-author, Problems of the New Cuba (1935).

1 The Export-Import Bank releases statements of its loans and commitments at irregular intervals. The figures as of Aug. 15, 1941, are taken from two articles by Warren Lee Pierson, President of the Bank, A Report to the American People, For. Commerce WeekLy, Aug. 30, I941, p. 3 et seq., and Sept. 6 , $194 \mathrm{I}$, p. 3 et seq. The figures in this statement do not include loans to American concerns in connection with their Latin American trade. These loans, of which the larger part is to the Intern. Tel. \& Tel. Co., are probably less than \$10 million. Mr. Pierson, in a speech before the American Bankers Association on Dec. $\mathrm{r}, 194 \mathrm{I}$, gave a figure of $\$ 300$ million for the total loans and commitments of the Bank in Latin America. 
supplies. Cuba repaid its indebtedness in full in $1923,{ }^{2}$ and Nicaragua's indebtedness was canceled in 1939 as part of a general settlement of claims between the United States and Nicaragua. ${ }^{3}$

The most extensive governmental credit operation involving Latin America until quite recently was not one made by the American government but was a credit of $\$ 100$ million in 1918 to the United States by Argentina. The purpose of this arrangement was to permit the importation of Argentine products without causing a severe pressure on the American dollar, already depreciated in terms of the Argentine peso as a result of wartime developments in American trade and monetary policy. This credit took the form of the delivery of pesos to the Federal Reserve Bank of New York in exchange for dollars deposited to the account of the Banco de la Nacion of Argentina, which the latter bank agreed not to draw upon for a specified period. The credit was repaid in the latter part of 1920, and the repayment helped to support the peso at that period, just as the original credit had supported the dollar in $1918 .{ }^{4}$

Private credit played an important role in our relations with Latin America in the nineteen twenties. Between I92I and I930 Latin American dollar bonds in excess of $\$ 2$ billion were marketed by American investment bankers. ${ }^{5}$ Making allowance for refunding, and for bonds held in Europe or repatriated, the funds made available to Latin America in this decade by American investors were in the neighborhood of $\$ 1,200$ million. ${ }^{6}$ In addition American businesses made extensive direct investments totalling over a billion dollars in South America alone and an additional two thirds of a billion in the remaining Latin American countries. ${ }^{\text {? }}$

These credits and direct investments were a factor in cushioning the drop in our export trade to Latin America after the economic collapse in 1920 and in making possible the substantial recovery in this trade after 1922, in the face of rising American tariffs on important Latin American exports. Even before the stock market crash of 1929, private American credits to Latin America had declined sharply. After 1930 American credits to Latin America, with the exception of public works loans to Cuba in I93r, virtually ceased. Wholesale defaults on Latin American dollar bonds, starting between I93I and I933 and continuing in most cases up to the present, practically eliminated the possibility of immediate resumption of extensive private credits to Latin America.

\footnotetext{
2 World War Foreign Debt Comm'n, Combined Annual Reps. (1927) 13.

${ }^{3}$ ReP. SeC'y Treas. (1939) 70.

- For details of this important but little-known episode in hemispheric finance, see Williams, Latin American Foreign Exchange and International Balances during the War (1919) 33 Q. J. EcoN. 422-425; Williams, Argentine Foreign Exchange and Trade since the Armistice (I92I) 3 REv. Econ. STrustics 50-52. The Uruguayan Congress in July, I9I8, also authorized a credit of \$20 million to the United States, but apparently the Federal Reserve Bank of New York made no use of it. Shortly before the Armistice a similar arrangement was proposed between Chile and the United States, but no action was taken in the matter.

${ }^{5}$ Madden, Nadler and Sauvain, America's Experience as a Creditor Nation (1937) 72, 77.

${ }^{8}$ Cleona Lewis estimates American holdings of Latin American dollar bonds at \$274 million in 1919 and at $\$ 1,565$ million in 1930. Lewis, AMERICA's Stake in INTERNATTONal INVESTMENT (1938) 652.

7 This is the figure given by Cleona Lewis for the increase in American direct investments between rgrg and r929. Id. at 606 .
} 
The Export-Import Bank: Operations prior to September, 1939

In the early years of the depression suggestions were made for the stimulation of our waning foreign trade by the extension of government credit, but the first definite step came with the organization of the Export-Import Bank. This bank was created by Executive Order, in February 1934, under the provisions of the National Industrial Recovery Act, and its creation was later ratified by an Act of Congress of January 3I, 1935. The primary purpose of the new bank was to finance trade with recently recognized Soviet Russia. Because of the breakdown in debt negotiations, the Bank never financed any Russian trade.

It apparently was the original intention of the Roosevelt Administration, in the Blue Eagle days of the NRA, to organize, under the authority of the Recovery Act, a separate bank for each foreign country as occasion for credits arose. In line with this idea, the Second Export-Import Bank was also organized in $x 934$ for the financing of trade with Cuba. The only credits this second bank extended were in connection with the purchase of silver by the Cuban government for minting at Philadelphia. ${ }^{9}$

With the failure of the Russian trade to develop, and the abandonment of the idea of separate Export-Import Banks for individual countries, the Second ExportImport Bank was liquidated in 1936 and the first Bank took over its activities. By various acts and Executive Orders the Bank's original capital of \$II million has been raised to $\$ 175$ million, of which all but $\$ \mathrm{I}$ million is preferred stock subscribed for and owned by the RFC. ${ }^{10}$ The common stock, subscribed for by the Treasury of the United States, is held jointly in the names of the Secretaries of State and Commerce, for the benefit and use of the United States, except for eleven trustees' shares. The management is in a board of eleven trustees, chosen by the common and preferred stockholders, and the policy has been developed of having officials of the Departments of State, Treasury, and Agriculture on the Board, but with representatives of the RFC in the majority. The Bank has authority to make loans up to $\$ 700$ million and the RFC is to furnish it with any funds needed for its operations. The Bank, as reorganized in 1936, was not intended primarily as a Latin American credit agency, and until the end of 1938 its Latin American activities, aside from the Cuban coinage loans, were an almost insignificant part of its business. Its activities up to that time were largely the financing of American agricultural exports to Europe and the extension of credits to China through a specially organized New York corporation, The Universal Trading Corporation.

\footnotetext{
${ }^{8} 49$ STAT. 4 (1935). For details of the Bank's organization and citation of the many laws and executive orders relating to it, see Whittlesey, Five Years of the Export-Import Bank (1939) 29 AM. Econ. REv. 487 .

${ }^{\circ}$ For details of the Cuban coinage loans, see Export-Import Bank Loans to Latin America (r94r) I7 For. Policy Rer. 88.

${ }^{10}$ The most recent legislation governing the banks, is the law of Sept. 26, I940, authorizing an increase in the lending power of the Bank from $\$ 200$ million to $\$ 700$ million, the increase being entirely for activities in the Western Hemisphere. 54 STAT. 962, $x_{5}$ U. S. C. A. $\$ 7 I_{3}$ (b) (Supp. 794I).
} 
The Bank explained in its report for 1936 that its operations had fallen in three main fields:

a) Ninety-day credits, in connection with the export of agricultural products, especially cotton and tobacco, where such facilities were not available through private financial institutions.

b) Credit directly to American firms desiring to export industrial products, particularly heavy machinery and railway equipment.

c) Loans to American exporters whose working capital has been reduced because of the failure of foreign governments to provide their own nationals with sufficient exchange to permit them to meet their dollar obligations.

The Bank stressed the fact that advances were made solely to further American economic interests and not in the interest of American foreign policy and that they were made only after careful consideration of the possibility of repayment. Total outstanding credits in connection with Latin American trade were only $\$ 2,234,000$ at the end of 1937 , of which $\$ 1,320,000$ was for the unblocking of balances in Brazil and the remainder to Mexico and Venezuela. It is true that in 1936 the Bank had made a commitment to American exporters, through the National Foreign Trade Council, to take over $\$ 27,75^{\circ}, 000$ of blocked balances in Brazil, but less than $\$ 1,800$,ooo of this commitment was ever taken up, and most of this was repaid by 1938 . We may say that the Export-Import Bank activities in Latin America up to the middle of 1938 were of minor significance, and such credits as were made there had no political objectives.

In June 1938, the Bank made its first Latin American commitment that seemed to be influenced by considerations of foreign policy: an agreement with the Haitian government to purchase up to $\$ 5$ million of notes to be issued to an American construction company in connection with an extensive public works program in that country. Although aid to American exporters was undoubtedly an element in the transaction, it would appear that it was political and economic conditions in Haiti, and not business conditions in the United States, that were the primary consideration in the loan. In December 1938 , it made \$1o million available to the International Telephone \& Telegraph Company for the development of its Latin American properties. In March 1939, it advanced \$19,200,000 to the Bank of Brazil to permit it to pay off frozen balances of American exporters, and also made a general statement that it would give favorable consideration to requests for longer-term loans for industrial developments in Brazil. At the outbreak of war in September, 1939, credits to Latin America, including the I. T. \& T. loans, totaled less than $\$ 30$ million, and, excepting the Brazilian, Haitian, and I. T. \& T. loans, credits were less than $\$ 600,000$. The Bank also had outstanding commitments of slightly less than $\$ 27$ million in Latin America.

The Export-Import Bank: Operations since September, 1939

In the months following the outbreak of war, commitments were made to extend credits to several Latin American countries, under circumstances that suggested that 
it was the expected economic and political effect of the loan in the borrowing country, rather than direct aid to American business, that prompted the action. However, very few of these commitments were taken up. As late as June 30, 1940, total loans in Latin America, including the I. T. \& T. loans, were only $\$ 22$ million-a smaller figure than at the outbreak of the war-although unused commitments had risen to over $\$ 80$ million.

Up to September 1940, no change had been made in the stated purpose of the Bank, and previous to that time Administration spokesmen had dealt very gingerly with the queries of Congressmen about loans in the interest of United States foreign policy, ${ }^{11}$ and on at least one occasion denied categorically that loans were made for the purpose of military supplies. ${ }^{12}$

Legislation of September 26 , I940 increased by a half billion dollars the lending power of the Bank and, by redefining its purposes, in effect made it an agency of American foreign policy. President Roosevelt, in requesting the passage of the new legislation, the Secretaries of State, Treasury, Commerce, and Agriculture, in their statements in support of it, and Mr. Jesse Jones in testifying before the Senate and House Committees, all made it clear that the purpose of the Export-Import Bank was henceforth to be very different from its original purpose of 1934 as an aid to recovery. ${ }^{13}$ The new law stated that the purpose of the increased capital was "to assist in the development of the resources, the stabilization of the economics, and the orderly marketing of the products of the countries of the Western Hemisphere." Secretary Hull said that the new legislation "will enable the United States to make its appropriate economic contribution to the carrying out of that program which is necessary to the safeguarding of the vital interests of the United States." Mr. Trimble, the Acting Secretary of Commerce, said: "This bill is part of a program of total national defense. ... The likelihood of loss through loan defaults cannot be ignored or minimized, but this possibility is inherent in the broad policy of which the bill is merely a single element." Mr. Jesse Jones admitted that under its new powers the Bank would consider loans to finance the purchase of military supplies by Latin American countries. ${ }^{14}$ The new role envisaged for the Bank is well epitomized in this interchange between Mr. Jesse Jones and Senator Adams:

Mr. Jones: There is no definite program in mind except to place the Bank in a position to do whatever might appear to be to the best interest of the United States.

Senator Adams: Simply to have a half billion dollars ready money to make use of in any way that the Bank thought might be of advantage to any country in the Western Hemisphere or any of its citizens?

Mr. Jones: I think that might be true. ${ }^{15}$

${ }^{11}$ See, e.g., testimony of Mr. Jesse Jones, Hearings before Senate Foreign Relations Committce on S. 3069,76 th Cong., $3 \mathrm{~d}$ Sess. (1940) $31,32$.

${ }_{12}$ Statement of Mr. R. Walton Moore, Counselor of the Department of State, id. at 43.

${ }^{13}$ Hearings before House Banking and Currency Committee on $H . R$. 10212, superseded by $H . R$. 10361 , 76th Cong., 3d Sess. (1940); Hearing before Senate Banking and Currency Committee on $S$. 4204 (1940), 76 th Cong., 3 d Sess. (1940).

it House Hearings, supra note 13 , at $31 . \quad \quad{ }^{15}$ Senate Hearings, supra note 13 , at 7. 
Following this new legislation, the Bank soon increased its commitments in Latin America. The most notable of these was one in December 1940 of $\$ 60$ million to the Central Bank of the Argentina for the purchase of American agricultural and industrial products, simultaneous with the announcement of the Treasury that it was prepared to advance $\$ 50$ million to the Central Bank of Argentina for stabilization purposes. Other important recent commitments are those of $\$ 33,200,000$ to Brazil, $\$ 36,300,000$ to Cuba, and most recently (November I8, I94I) $\$ 30$ million to Mexico for road construction. In addition to these commitments, the Bank on October 29, r94I, made an important announcement of policy in declaring its willingness to underwrite, for the financing of American exports, short-term credits opened by American banks at the request of Latin American commercial banks, subject to certain conditions and within quotas to be worked out by the central banks of the respective countries. ${ }^{16}$ At present writing (December $\mathrm{I}$, r94I) the specific commitments to Latin America, aside from whatever commitments are implied in the Bank's statement of October 29, cover every South American country except Bolivia and all of the Caribbean and Central American republics except Guatemala, Honduras and Salvador. The following table gives the details of the growth of the Bank's

Export-Import Bank Loans to Latin America ${ }^{1}$

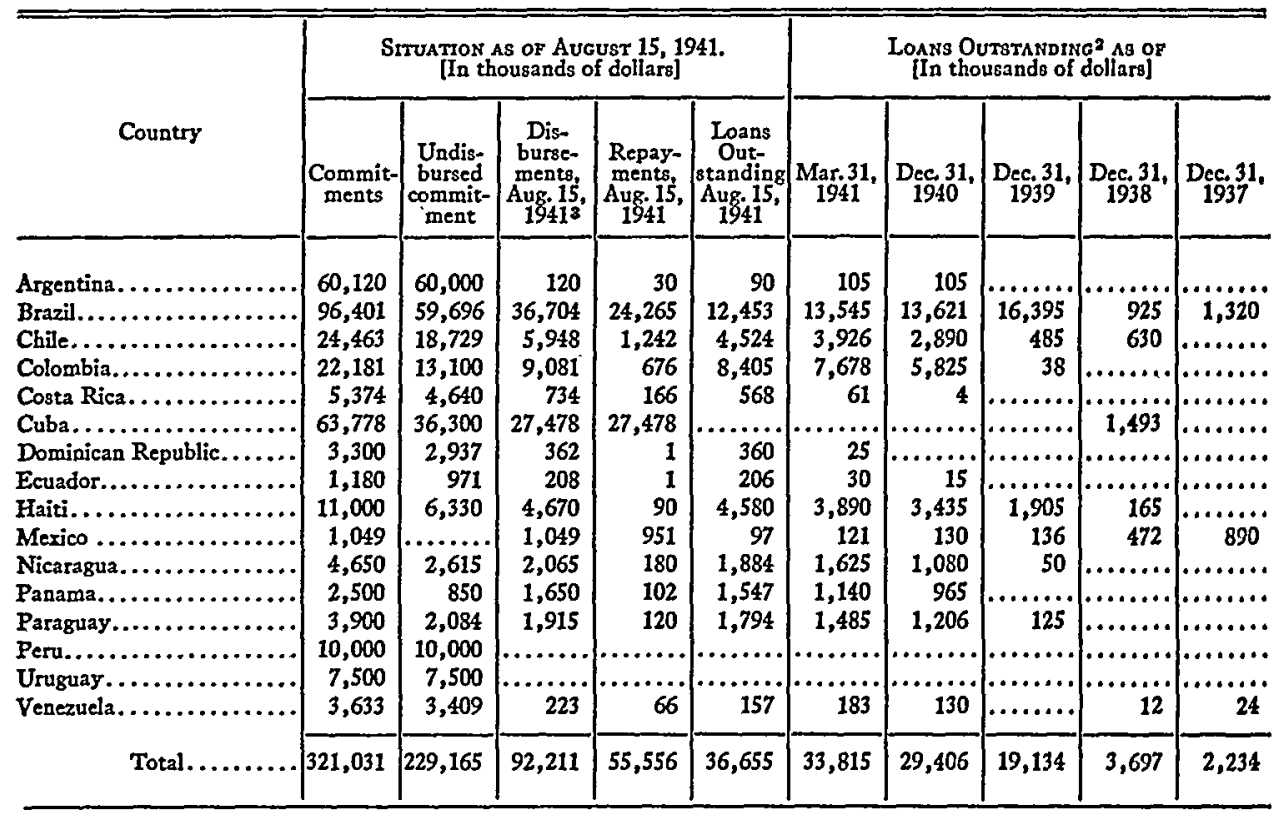

1 Figures for outstanding loans from December 31, 1937 to March 31, 1941, are from the Federal Reserve Bulletin, May 1941, p. 386; figures for August 15, 1941 are from an article by Warren Lee Pierson, President of the Bank, Foreign Commerce Weekly, p. 386; figures for August 15 , 1941 are from an article by Warren Lee Pierson, President of the Bank, Foreign Commerce
August 30,1941, p. 33 . This table does not include the loans to the International Telephone and Telegraph Co.

August $30,1941, p .33$. This table does not include the loans to the Intermational Telephone and Telegraph Co.
2As of December 31, 1935, the Bant had loans outstanding of $\$ 4,112,000(\$ 4,062,000$ to Cuba), and as of December 31, 1936, 2As of December 31,1935 , the
$\$ 1,673,000(\$ 1,064,000$ to Cuba).

37,000 ( $\$ 1,064,000$ to Cuba). not check with the difference between the figure for commitments and undisbursed commitments. The discrepancies are in all cases small, and do not affect the general picture.

${ }^{18}$ For an account of this proposal, see Egan, U. S. Will Finance Latin Purchases, N. Y. Times, Oct. 30, r94I, p. 35. The proposal is explained by President Pierson of the Bank in Solving Two Pan-American Trade Problems, For. COMMERce WeEkLy, Nov, I, I94I, p. ro: 
outstanding loans in Latin America, and the status of its loans and commitments as of August 15, I94I.

These operations, including unused commitments as well as credits utilized, fall in three broad groups: (I) Short-term credits intended for meeting seasonal or emergency shortages in exchange, (2) long-term industrial development credits, and (3) long-term credits for road building. There are, in addition, two other types of credits which seem to have been contemplated by the Administration when the power of the Export-Import Bank was expanded in I940 but which as yet have not been made: those for withholding from the market Latin American export products and those for the purchase of military supplies in the United States.

The first type of credits are similar to those that commercial banks might make and have made in the past, except that in the present state of economic and political uncertainty in Latin America it is unlikely that private banks would be willing to grant sufficient credits to prevent the disruption of trade. The credits that the ExportImport Bank has made available to a number of central banks to finance American exports are the examples of this type of operation. If granted in moderate amounts, and if they remain in fact what they appear to be-short-term, revolving credits, they can be an important factor in preventing wartime trade developments from disrupting trade and upsetting exchange rates. With a return to peacetime conditions, such credits should not present serious problems of repayment, particularly if the United States moves toward lower, rather than higher, tariffs on Latin American products.

In making long-term developmental credits the Bank is in substance acting as an investment banker, financing enterprises that even if successful will yield revenue that will permit repayment only after some years in the future. The \$20 million commitment to Brazil to erect a steel mill, and the large commitments to the Brazilian and Chilean railroads and to the Development Corporation of Chile, are of this type. Their repayment presents a far more serious problem than does that of the short-term credits. Only if these enterprises are financially successful will funds be available for repayment, and even then only if the exports of those countries can find a market in the United States in the post-war period, will it be possible to turn local currency into dollars without great strains.

The third type of credits, those for public works, presents the same problem as the second but in a more acute form. These public works will yield no direct return to pay interest and amortization, and only insofar as they provide a basis for the collection of more taxes by the borrowing countries can they be repaid without involving a burden on the national budget and on the taxpayer.

The credits and commitments of the second and third class to date have been made with unusual discrimination and have been held to a surprisingly small figure. It is really remarkable how far the management of the Bank has resisted the pressure for outright political credits, in view both of the strength of the "spending" group in the Roosevelt Administration and the evident intention, in the legislation of September, I940, to have the Bank make loans without too much thought of their repay- 
ment. It is probable that Mr. Warren Lee Pierson, the President of the Bank, has been an important influence in preventing the Bank from going in heavily for the type of political loans contemplated in I940, and, if the Bank escapes substantial losses on its Latin American credits, it will be largely due to his policy in holding it to some approximation to business standards. ${ }^{17}$ It is quite possible that his attitude explains why the Bank has made no loans for the withdrawal of surplus products from the market, and why operations which might have been taken the form of Export-Import Bank credits have been handled by the various defense corporations created by the RFC. ${ }^{18}$ Credits to date should present no serious problem of repayment, but as existing commitments are taken up and particularly if extensive new commitments are made to finance industrial developments and non-revenue-producing public works, the economic and political consequences of these credits may become serious. An attempt to force repayment may well bring into our relations with Latin America the same unfortunate results as the attempt to collect the war debts brought into our relations with Europe two decades earlier.

In a period of emergency, foreign policy cannot be expected to give great importance to long-run economic considerations, yet some thought must be given to the future if our Latin American credit operations are not to be a disturbing factor for many years. Granted that some governmental credits must be extended in the interests of American foreign policy, even in the short run there are possibilities of an adjustment of American trade policy to encourage the building up of dollar balances by means of exports rather than by loans. Every dollar that can be made available to Latin America through exports laid down in the United States, or through tourist travel to South America, means so much less need for governmental credits and by that amount reduces the necessity of future economic adjustments and the danger of political friction. The Roosevelt Administration has already taken some notable steps in this direction, most recent of which was the Argentine trade agreement of November, r941. Yet much remains to be done. Unless we are prepared to cancel this indebtedness when peace comes-something that American public opinion almost certainly would not stand for even if it were otherwise desirable-we must be willing to encourage imports from Latin America. But if past experience is any criterion the coming of peace will probably bring demands from the public that Latin America pay, and at the same time strong pressure will be put upon Congress to exclude all agricultural and mineral products directly competitive with our own. Signs of this are already apparent in a public attitude that it is all right to buy Latin American products in the present emergency, but that such a situation ought not to continue once the emergency has passed. What the final

\footnotetext{
${ }^{17}$ In his article in Foreign Commerce Weekly, Aug. 30, 1941, supra note 16, Mr. Pierson, referring to the Bank's statement, says: "I would like to point out the fact that in it you will not find any accounts, loans, enterprises or activities of a purely sentimental value. It has been our intent to leave sentiment, philosophy, politics, diplomacy, charity, and wishful thinking to other institutions or individuals of a philosophical or philanthropical turn." This is a point of view different from that expressed by Administration spokesmen when urging the enlargement of the Bank's authority in 1940.

${ }^{18}$ See pp. 730-732, infra.
} 
consequences of these credits will be for the economic and political stability of the Western Hemisphere depends largely upon the trade policy that the American public will support.

The importance, for our trade relations to date, of these operations of the ExportImport Bank and the Stabilization Fund, depends very largely on the amount of credits that are actually used as distinguished from the commitments that are not taken up. The effect of the former is clear: they enable Latin American countries either to make purchases in the United States or to build up reserve balances here, which in effect usually has the same result as increasing their ability to buy American goods. ${ }^{18}$

A more difficult question to answer is: what is the influence of a commitment to extend credit when no use is made of the credit? Perhaps such a promise enables an American manufacturer to make a sale that he would not have made without the Export-Import Bank's commitment to handle the financing if necessary, or perhaps the Central Bank of Argentina as the result of the assurance that dollars will be forthcoming from the Stabilization Fund in case of emergency, furnishes to Argentine importers dollars that it otherwise would have been unwilling to supply. It is also possible that in the present state of international relations such commitments, even though never used, may be a factor in strengthening the hand of pro-American groups in the Latin American countries. This is clearly in the realm of political imponderables, but it is in such terms, rather than in straight commercial terms, that any realistic appraisal of the immediate significance in the Latin American field of credit operations of American governmental agencies must be made.

\section{The Operation of the Silver Purchase Program}

Narrowly interpreted, the term governmental credit only covers those transactions involving a loan by an American government agency, or at least a commitment to make a loan. The outright purchase and storage of Latin American products does not involve a loan. Yet it has practically the same immediate consequences in the field of hemispheric trade as have direct credit operations. The important differences are that, in the case of a purchase, no one in Latin America is placed in a debtor relationship to the American government and if the commodities fall in price the loss falls directly on the American government. In view of the large scale on which such purchases have been made since I934, they have to date been a far greater influence on hemispheric trade than have government credit oprations.

The most important case in dollar terms of such a use of government funds to take Latin American products off the market, is the operation of the Silver Purchase

${ }^{10}$ The distinction so frequently drawn between credits to stabilize exchange and those to finance the purchase of American goods, is largely meaningless. The principal reason why some South American countries have had such diffculty in maintaining the stability of the dollar exchange rate is that they have not been able to secure a sufficient supply of dollars to pay for their imports, and hence they are faced with the alternative of drastic reduction of imports or a reduction of dollar balances that puts their currency at a discount with relation to the dollar. Under these circumstances, credits from the Stabilization Fund or the Export Bank to stabilize exchange would simply replace dollars that had previously been used up in paying for imports from the United States. 
Act of May 1934, which made it the policy of the United States to purchase silver until the price is $\$ 1.29$ an ounce, or until such time as the country's monetary stocks of silver are equal to one third of its gold stocks. Under that act the Treasury has apparently purchased between $\$ 300$ million and $\$ 325$ million of Latin American silver. ${ }^{20}$ On the face of the record, the placing at the disposal of South American exporters of such a large amount of dollar exchange was simply an unintended result of carrying out the mandate of Congress in the field of domestic monetary policy. Yet it is almost certain that the amount of the purchases, and even the price that has been paid, have been influenced by considerations of foreign policy. ${ }^{21}$ Regardless of the intent, the result is clear: various Latin American countries have had available large amounts of dollar exchange, thus making possible larger purchases in the United States and making less necessary, in the interests of American policy, credits by the Export-Import Bank or other government agencies.

\section{Purchases and Credit Operations by Defense Corporations}

Since the middle of 1940 , purchases in Latin America of strategic materials as part of our defense program have introduced a new factor into hemispheric trade. By an Act of June 25, I940, the RFC was authorized to buy the capital stock of, and to make loans to, any corporation "for the purpose of producing, acquiring and carrying strategic and critical materials as defined by the President, and to organize any corporations for this purpose." Three corporations were organized for this purpose in the summer of r940, all completely controlled by the RFC: the Metals Reserve Company, the Rubber Reserve Corporation, and the Defense Supplies Corporation. They have already purchased and are holding large quantities of Latin American materials and have made commitments to acquire much larger amounts of future production. In some cases they have made advance payments to facilitate production or shipment and in at least two cases have made outright loans.

According to the latest available statement, as of September ${ }_{13}$, I94I $^{22}$ their more important operations in the Latin American field were as follows:

20 The Treasury does not publish a separate figure for purchases of Latin American silver, but from the figures on total foreign purchases and imports of silver from the Latin American countries, it would appear that the purchases of Latin American silver are about this amount. TreAs. Dep'r Burl. (Oct. 194I) 79-8I.

${ }^{21}$ In December 1937, Secretary Morgenthau and the Mexican Minister of Finance announced that arrangements had been reached with Mexico in regard to the basis on which our silver purchases were to be made. On March 18, 1938, the Mexican government issued a decree expropriating American oil properties, and nine days later Secretary Morgenthau issued this statement: "In view of the decision of the Government of the United States to re-examine certain of its financial and commercial relationships with Mexico, the Treasury will defer continuation of the monthly silver purchase arrangements with Mexico until further notice." REP. SEC'y TREAS. (I938) 268.

On Nov. 19, 1941, Secretary Morgenthau and the Secretary of the Treasury of Mexico issued a joint statement of a stabilization agreement and a silver purchase agreement, and said that "these arrangements are practical evidence of the Good Neighbor Policy." On the same date, the Export-Import Bank announced a credit of $\$ 30$ million to Mexico for road construction, and Secretary Hull released a note indicating that a formula had been reached for the settlement of the oil expropriation dispute.

${ }^{22}$ Federal Loan Administrator Jesse Jones has presented to Congress and released to the press threc statements on the operations of these corporations, as of Jan. 6, April 30, and Sept. 13, 1941. The last release does not in all cases give separately the Latin American activities of the Metals Reserve Company, 


\begin{abstract}
Amount of Purchase and Commitment

Commitment to purchase up to 60,000 tons of Brazilian rubber in $194 \mathrm{I}, 1942$

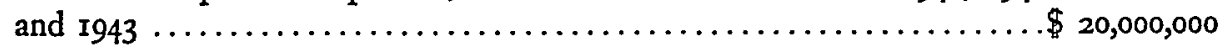

Metals Reserve Company

Amount of Purchases and Commitments

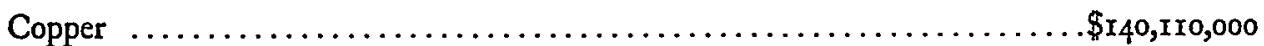

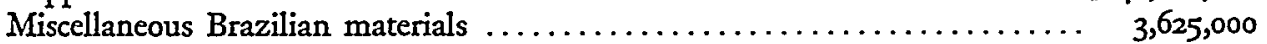

Miscellaneous Mexican materials .......................... 2,576,000

Miscellaneous Peruvian materials ........................ 2,000,000

Other materials (principally manganese, tin, and tungsten) Approximately 225,000,000

Total purchases and commitments.................. Approximately $\$ 375,000,000$

Since the report of September I3, I94I the Metals Reserve Company has made public two more important commitments to take over South American products. On October 2 it announced that it had made an arrangement with Peru whereby "certain strategic and critical materials are made available exclusively to the countries of this Hemisphere." The agreement covers antimony, copper, lead, tungsten, vanadium and zinc. No definite figure was announced, but the Metals Reserve Company will buy for government stockpile all of these materials that are not purchased by the private trade in the United States. On November 28, it announced that it would buy the Argentine tungsten production for the next three years at a guaranteed price. These commitments to purchase output of particular products, like a commitment to Mexico in July, I94I, are in effect our quid pro quo for the agreement of the Latin American country to embargo exports of those products to countries outside of the Western Hemisphere.

Defense Supplies Corporation

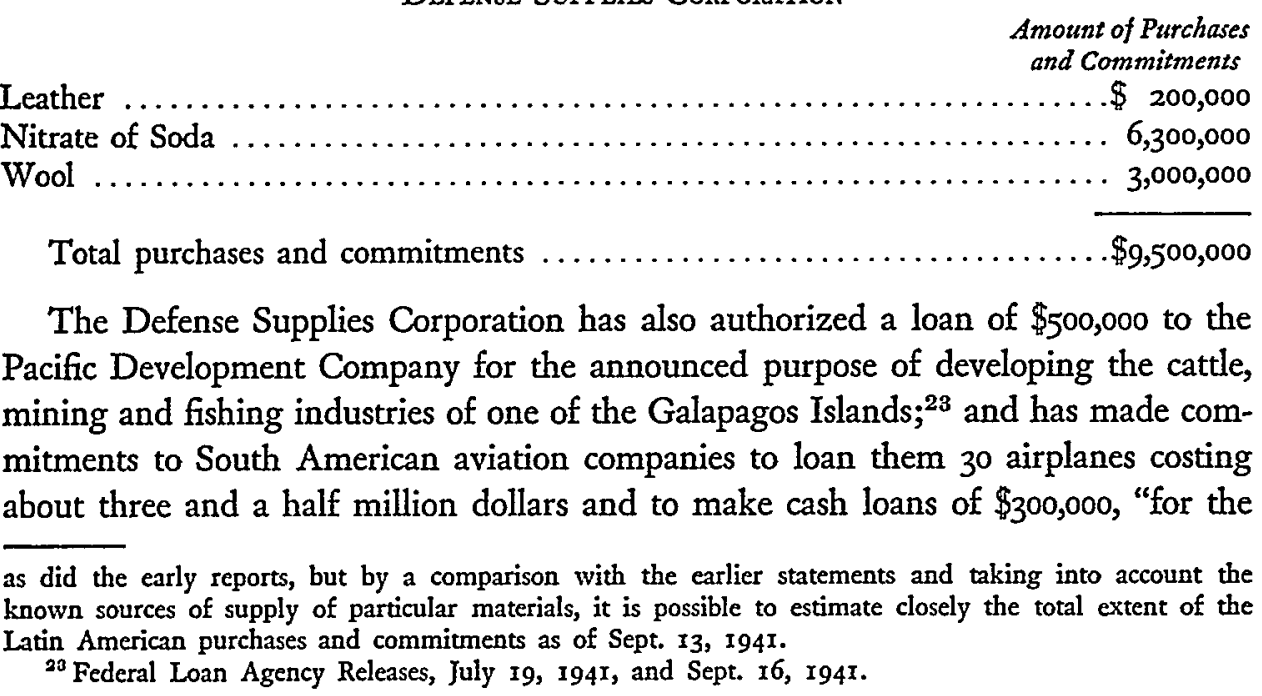


purpose of the development of transportation facilities in the other American Republics to facilitate trade between those countries and for other purposes affecting our national defense."24

The operations of these three defense corporations have undoubtedly had important effects on our trade with Latin America. Yet to evaluate their significance in this regard as distinguished from that in the national defense program, is extremely difficult. The mere fact that the government happens to be the buyer, rather than an American commercial concern, would not increase the supply of dollar exchange if these corporations simply act as purchasing agencies, and at once released their purchases to the commercial trade. It is when they withdraw products from the market by building up stockpiles that the result is essentially that of a credit operation. About all that can be said is that these defense corporations have already made available to Latin American countries, in varying forms, some millions of dollars of dollar exchange that otherwise they would not have had and that this is likely soon to be increased by tens, if not hundreds, of millions more.

\section{The Relations between Government Credit and Defense Agencies}

It is impossible to separate the effects of what are strictly credit operations from the effects of purchases and commitments to purchase. Today all government economic operations in the Latin American field, regardless of the particular form that they take, the ostensible purpose for which they are undertaken, or the particular agency that happens to handle them, are simply part of the foreign policy of the United States. The distinction between an Export-Import Bank loan of the type contemplated when the lending authority of the Bank was increased in 1940 to permit Latin American countries to carry surplus products, and the commitments made by the defense corporations to purchase output otherwise unsalable or that would be sold to an Axis power, is in effect practically nil. There are at least five government agencies that are in a position to make dollar exchange available in Latin America, and there are at least a half a dozen ostensible purposes for which that exchange may be made available. The decision as to which agency is to handle a transaction and what particular form it will take, is the result of traditional divisions of authority within the government, of clashes of personality, of issues of prestige, of the government's desire to present the transaction so as to make a favorable public impression, or the desire of particular organizations to avoid certain types of operations, and, in the last analysis, of President Roosevelt's decision.

The announced or clearly implied purposes of the various transactions undertaken since $r 934$ include the following:

I. Stimulation of our export trade in the interests of American business and agriculture.

2. Stimulation of economic developments in Latin America that are believed to be in the interests of the United States.

3. Prevention of economic and political disturbances in Latin America.

4. Stabilization of exchange rates with the United States.

${ }^{24} I d .$, Sept. r6, r941. 
5. Acquisition of strategic materials to build up supplies in the United States.

6. Cutting off supplies of strategic materials from other countries.

The Export-Import Bank, the Treasury, the Defense Supplies Corporation, the Rubber Reserve Corporation, and the Metals Reserve Company, all have authority to further one or more of these objectives, and in addition the Federal Reserve Banks could undoubtedly play a part if necessary. ${ }^{24^{2}}$ As far as the law goes, there is no operation that could not be handled in some way by any one of these agencies. The Treasury can extend credits from the Stabilization Fund to a central bank for the announced purpose of stabilizing exchange, and that central bank can in turn make loans to withdraw from the market strategic materials that would otherwise fall into the hands of an Axis government. The Metals Reserve Company can purchase, or make advances on, strategic materials, even though there is no need for the materials in the United States and no danger of their falling into Axis hands, when the real purpose is to provide dollar exchange to bolster up the currency of a Latin American country. This is not to say that the organizations will in practice operate in this way, but it is well to recognize that they have ample authority to do so.

\section{The Future of Governmental Credit and Hemispheric Trade}

Any appraisal of the future of these operations hinges on developments in the international field. As long as this was lasts, presumably operations will continue with little regard to the eventual economic outcome. Yet even in a period of emergency some general considerations of the future should be kept in mind. So far as possible we should aid the Latin American states by permitting our citizens to buy their products rather than by granting them loans; so far as credits and outright governmental purchases may be alternative policies in particular cases, the purchase procedure is generally preferable as less likely to lead to later international friction.

With a German defeat, almost certainly the defense corporations will cease their activities in Latin America. There are three types of operations that might be undertaken by the Export-Import Bank or the Stabilization Fund in a post-war era: (I) credits in connection with marketing problems at the end of the war, (2) provision of long-term capital for developmental purposes, and (3) operations in connection with the establishment and maintenance of a dollar exchange standard.

In the first field there may well be a substantial task to be done, and the ExportImport Bank would be an institution well equipped to carry out such operations.

\footnotetext{
s4x Recent information indicates that extensive credit commitments have been made to Latin American countries under the Lend-Lease program, although it is not clear whether any of these countries have made use of such credits. President Roosevelt's second Report on the Lend-Lease Act, as of Sept. II, I94I, had listed requisitions received from Brazil, Chile, and the Dominican Republic, but at that time the only materials delivered to Latin America had gone to Brazil and the Dominican Republic on a cash basis. The N. Y. Times of Dec. 7, r94r, reports the signing of a Lend-Lease agreement with Bolivia for any amount said to be from $\$ 10,000,000$ to $\$ 15,000,000$, and states that Lend-Lease pacts are also known to have been signed with Brazil, Haiti, the Dominican Republic, Paraguay, Nicaragua, and Cuba. These operations under the Lend-Lease program may explain why the Export-Import Bank has not made the loans for the purchase of military supplies that were contemplated when the authority of the Bank was expanded in Sept., 194r.
} 
Long-term developmental loans present a different problem. However desirable for the Latin American countries such developmental loans might be, any government that engages in extensive lending of this sort should be prepared to write off a substantial part of the loans.

In the post-war period there may be a role to be played by some agency in the interests of inter-American monetary cooperation. The gold standard of the pre-193x days is dead, and for the Latin American countries any monetary stabilization will almost certainly for some years to come involve a tie to the dollar. No agency of our government can expect to maintain monetary stability in a Latin American country in the face of monetary inflation there, and stabilization credits under such conditions would be unfortunate. But there would be a real service to be performed by some agency in the United States that could furnish to the central banks of Latin America credits to take care of seasonal and emergency situations. Such stabilization operations could be handled by the New York Federal Reserve Bank or by the Treasury. There are strong arguments in favor of having a central bank handle such monetary operations rather than the Treasury. Yet the trend in the United States since 1933 has been for the Treasury to take over the monetary powers previously in the hands of the Federal Reserve System, and it is doubtful whether the Treasury will, without a struggle, return these powers, including those connected with international stabilization operations.

\section{An Inter-American Bank}

It is possible that a new agency, an inter-American bank, may soon enter the field of hemispheric credit. The proposal for such a bank goes back nearly fifty years, ${ }^{20}$ but until 1939 it never got past the stage of general discussion. As an outgrowth of the meeting of the foreign ministers of the American republics in Panama in 1939, a plan for an inter-American bank was formulated early in 1940, and the convention for its establishment was signed in May r940 by the United States, Colombia, Dominican Republic, Ecuador, Mexico, Nicaragua, Paraguay, Bolivia, and Brazil. In July 1940, President Roosevelt requested the Senate to ratify the convention. After hearings in May I94I ${ }^{26}$ before a subcommittee of the Committee on Foreign Relations, the measure was referred to the Banking and Currency Committee for its advice. There it rests, and any further developments in the organization of the Bank await senatorial approval.

The proposed bank is to have an authorized capital of \$roo million, and the only stockholders are to be the governments of the participating countries. Each government must subscribe for stock, on the basis of its foreign trade, the compulsory sub-

\footnotetext{
${ }^{25}$ For an account of the movement for the establishment of an international bank and details of the proposal, see Villaseñor (Director-General of the Bank of Mexico), The Inter-American Bank: Prospects and Dangers (1941) 20 For. AFFalns r65-174.

${ }^{20}$ Hearings before a Subcommittee of the Senate Committee on Foreign Relations on Executive $K$ (76th Cong., $3 \mathrm{~d}$ Sess.), 77th Cong., rst Sess. (194I). The text of the convention, signed in May 1940, and the proposed charter and by-laws of the Bank appear in these hearings, and also in (1940) 2 STATE Dep't Bull. 512; (1940) 26 Fed. Reserve Burl. 517.
} 
scriptions ranging from a minimum of $\$ 500,000$ to a maximum of $\$ 5$ million for Argentina, Brazil and the United States. These compulsory subscriptions, if all of the countries join, will furnish $\$ 43,500,000$. The remaining capital is open to voluntary subscription by the participating governments. The Bank is to have its principal office in the United States, with at least one branch or agency in each of the other participating countries. The management is to be in the hands of a board, elected by a system that gives each government an equal vote on the basis of its compulsory stock subscription. Additional voting rights are given on the basis of voluntary stock subscriptions, but no government is to have more than one third of the voting rights. On this basis, if each government makes only the minimum subscription, the United States will furnish about $\mathrm{II} \%$ of the capital and have less than $5 \%$ of the voting rights; if the United States should subscribe to the entire additional $\$ 56,500,000$, it would have approximately $60 \%$ of the capital, and one third of the voting rights.

The role played by such an inter-American bank will be determined largely by the policy of the United States on supplying it with funds. It seems to be a foregone conclusion, implicit both in the attitude of the United States and of the Latin American countries, that the United States will furnish the larger part of the resources and that the Latin American countries will receive the loans. A proposed bill authorizes the RFC to buy stock in the Bank up to $\$ 25$ million. It also authorizes the RFC and the Export-Import Bank to make loans to the Inter-American Bank and to purchase its debentures, and places no limit on the amount of these loans and debentures. ${ }^{27}$

Even if there is a need for a government agency that can make loans in Latin America when the present emergency is passed, serious doubts must arise as to the usefulness of this proposed institution. There is no lack of existing machinery, either private or governmental, to finance hemispheric trade. There are now more branches of American banks in Latin America than are needed, in view of the hostile attitude toward foreign banks in a number of countries. The Export-Import Bank and the Stabilization Fund have ample authority to act where private banks are not prepared to step in. The new Bank could do nothing that could not be done now, and its loans will present the same problem of repayment as are now presented by credits of any other institution.

Taking the long view, it is likely that the one unique service that an interAmerican bank could perform would be to provide a meeting place for the central bankers of the Western Hemisphere, where problems connected with the maintenance of exchange stability could be worked out in an atmosphere free from suspicions of Yankee imperialism. The Inter-American Bank might be a useful agency for coordinating monetary programs, and if necessary providing short-term stabilization credits that otherwise would come from the Federal Reserve Banks or the Stabilization Fund of the Treasury. It is along such lines, rather than as an

${ }^{27}$ The text of this bill is published in the Senate Hearings, supra note 26 , at 13. 
agency for putting American capital into long-term Latin American credits, that the opportunity lies for an inter-American bank.

The most important need in our economic relations with Latin America is not more financial machinery but a public recognition of what is back of the successful operation of existing machinery. No banking or financial institution can accomplish more than the underlying movements of goods and services will permit. A bank, no matter how complicated its organization may be, or how imposing its statement of policy may sound, can do nothing to bring about long-run international adjustments unless there is a flow of goods and services. It cannot stabilize exchange rates between the United States and Latin America if Latin American countries follow inflationary monetary policies, as several have done in recent years. There are already adequate agencies for doing, either in war or in peace, whatever needs to be done in the field of hemispheric credit, and the proposal for the establishment of another institution is likely to blind Americans, both north and south of the Rio Grande, to the fundamentals of inter-American economic relations. 